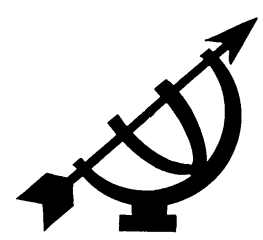

\title{
Metaphors, domains and embodiment
}

\author{
M. Elaine Botha \\ Professor of Philosophy (Emerita) ${ }^{\mathbf{1}}$ \\ Potchefstroom Campus \\ University of the North-West \\ POTCHEFSTROOM \\ E-mail: e botha@redeemer.on.ca
}

\begin{abstract}
Metaphors, domains and embodiment

Investigations of metaphorical meaning constitution and meaning (in-) variance have revealed the significance of semantic and semiotic domains and the contexts within which they function as basis for the grounding of metaphorical meaning. In this article some of the current views concerning the grounding of metaphorical meaning in experience and embodiment are explored. My provisional agreement with Lakoff, Johnson and others about the "conceptual" nature of metaphor rests on an important caveat, viz. that this bodily based conceptual structure which lies at the basis of linguistic articulations of metaphor, is grounded in a deeper ontic structure of the world and of human experience. It is the "metaphorical" (actually "analogical") ontological structure of this grounding that is of interest for the line of argumentation followed in this article.
\end{abstract}

Because Johnson, Lakoff and other's proposal to ground metaphorical meaning in embodiment and neural processes is open to being construed as subjectivist and materialist, I shall attempt to articulate the contours of an alternative theory of conceptual metaphor, meaning and embodiment which counteracts these possibilities. This theory grounds metaphorical meaning and meaning change in an ontological and anthropological framework which recognises the presence and conditioning functioning of radially ordered structures for reality. These categorisations in which humankind, human knowledge

1 Prof. Elaine M. Botha was also Professor of Philosophy at Redeemder University College, Ancaster, Ontario, Canada. 
and reality participate, condition and constrain (ground) analogical and metaphorical meaning transfer, cross-domain mappings, and blends in cognition and in language, provide the basis for the analogical concepts found in these disciplines.

\section{Opsomming}

\section{Metafore, betekenisdomeine en beliggaming}

'n Ondersoek na die wyse waarop metaforiese betekenis gevorm en gewysig word, het die belangrikheid van semantiese en semiotiese domeine, asook die konteks waarbinne dit funksioneer as basis vir die begronding van metaforiese betekenis, aan die lig gebring. In hierdie artikel word enkele huidige pogings ondersoek om metafoorbetekenis te begrond. Die voorlopige instemming met Lakoff, Johnson en andere aangaande die "konseptuele" aard van metafore berus op 'n belangrike voorbehoud, naamlik dat hierdie liggaamlik gebaseerde konseptuele struktuur, wat die basis is van die linguistiese verwoording van metafore, gegrond is op ' $n$ dieper ontiese struktuur van die wêreld en van menslike ervaring. Die "metaforiese" (of eintlik die "analogiese") ontologiese struktuur van hierdie begronding is veral belangrik vir die beredeningslyn in hierdie artikel.

Omdat Lakoff, Johnson en andere se voorstel om metaforiese betekenis te begrond in beliggaming en neurale prosesse sigself daartoe leen om subjektivisties of materieel verklaar te word, word in hierdie artikel gepoog om die kontoere van 'n alternatiewe teorie oor konseptuele metafore, betekenis en beliggaming te ontgin waarin bogenoemde moontlikhede uitgeskakel word. Hierdie teorie begrond metaforiese betekenis en betekenisverandering in ' $n$ ontologiese en antropologiese raamwerk wat die aanwesigheid en bepalende funksionering van straalvormig geordende werklikeidstrukture erken. 'n Basiese uitgangspunt van die voorgestelde idee van beliggaming is 'n ontologie wat die straalvormige, strukturele stratifikasies en kategorisering van menslike sisteme, kennis, ervaring en werklikheid erken. Hierdie kategoriserings waarin die mens, menslike kennis en werklikheid deel het, kondisioneer en begrens (begronde) analogiese en metaforiese betekenisoordrag, oor-en-weer-kartering van domeine, waarnemings- en taalversmelting, en voorsien die basis vir analogiese konsepte wat in die verskillende dissiplines aangetref word.

\section{The "grounding hypothesis"}

Recent developments in cognitive semantics (Lakoff \& Johnson, 1988:119-154; Johnson, 1987; Johnson, 1993b:61) and cognitive 
semiotics address the problem of how metaphorical meaning is possible through discussions of the "grounding" of metaphorical meaning. Where metaphors allow us to understand one domain of experience in terms of another (Lakoff \& Johnson, 1980:117), it is generally argued or assumed that metaphorical understanding is grounded in non-metaphorical understanding (Lakoff \& Turner, 1989:113), an assumption characteristic of most reductionist theories of metaphor. The question raised in this article is to what extent Lakoff, Johnson and Turner's move away from grounding metaphorical meaning in literal language to autonomous concepts grounded in patterns of bodily and social experience, actually solves the problem of the grounding of metaphorical meaning without succumbing to either subjectivism or materialism. I intend to argue in order to escape this trap, that this move to ground metaphorical meaning in bodily experience requires a further recognition of the ontological and anthropological stratification which conditions meaning and meaning variance. Philosophical insights from the philosophy of Herman Dooyeweerd's so-called Amsterdam School, will be utilised in this analysis.

\subsection{Literal meaning theory is about conventional language}

Lakoff and Turner argue that the literal meaning theory is not about concepts but about ordinary, conventional language which is seen to be semantically autonomous. Their grounding hypothesis deals with concepts as embedded in human experience. They do not deny that there are semantically autonomous concepts but claim that whatever such concepts, they "... are grounded in our patterns of bodily and social experience" (Lakoff \& Turner, 1989:119). To these issues and the issue concerning the grounding of orientational, basic, ontological and structural metaphors they answer that they are grounded ".. by virtue of systematic correlates within our experience" (Lakoff \& Johnson, 1980:58, 61).

In order for metaphors to allow understanding one domain in terms of another, there must be some "... grounding, some concepts that are not completely understood via metaphor to serve as source domains" (Lakoff \& Turner, 1989:135).

\subsection{The problem of grounding the conceptual system}

In the earlier work of Lakoff and Johnson (1980:56) the problem of grounding the conceptual system was briefly articulated as follows: "Are there any concepts at all that are understood directly, without metaphor? If not, how can we understand anything at all?" Concepts 
that are candidates to be understood directly are plants, departures, fire, sleep, locations, seeing, etc.

Lakoff and Johnson claim that there is a difference between their grounding hypothesis and the literal meaning theory. Their "grounding hypothesis" which is about concepts and not about language, indicates that only some concepts are "semantically autonomous", yet most concepts are not semantically autonomous (Lakoff \& Turner, 1989:119). In their position the term literal has been relegated to be used as handy term either for a source domain of a metaphor or to contrast with such terms as "ironic," "understated," "arrived at by principles of the conversation", etcetera (Lakoff \& Turner, 1989:119).

\subsection{The need to differentiate between experience and conceptualisation}

Lakoff and Johnson (1980:59) emphasise the need to differentiate between experience and the way it is conceptualised and argue that "... there are natural dimensions of experience and that concepts can be analysed along these dimensions in more than one way" (1980:76). Lakoff and Johnson argue that understanding takes place in terms of entire domains of experience and not in terms of isolated concepts and argue that domains of experience are conceptualised as experiential gestalts - structured wholes - that represent a coherent organisation of experiences in terms of what is experienced as "natural kinds of experience" (Lakoff \& Johnson, 1980:117). Their analysis of a host of empirical examples leads them to their conceptual metaphor theory which assumes the existence of these experiential domains. In Philosophy in the flesh (1999) where they inter alia deal with the grounding of metaphorical meaning, they propose an empirically grounded (responsible) philosophy which is not grounded in a priori assumptions. The target of their project is the dominant objectivist treatment of language, meaning, understanding and reasoning which does not take into consideration the bodily experience and figurative process of ordering.

Conceptual metaphor theory has proven to be most useful and fertile for the understanding of metaphorical meaning creation. It is, however, exactly the architecture of these domains (Brandt, 2000) at stake in the processes of cross-domain mapping and meaning transfer through metaphor, that requires further exploration. Lakoff and Johnson's understanding of "domains" require closer exploration, mainly in order to clarify the nature of domains and to 
delineate the relationship between conceptual metaphors, the experiential gestalts they are based upon and the pre-theoretical and pre-conceptual nomic conditions which condition and constrain domains.

\section{Conceptual metaphor, embodiment and the "grounding hypothesis"}

Conceptual metaphor theory claims that "... the magnificent tool of conceptual metaphor" (Lakoff \& Johnson, 1999:233) "... is one of the greatest of our intellectual gifts" (Lakoff \& Johnson, 1999:45, 129). Metaphors are pervasive both in thought and in language, and in human subjective experience in general. A large system of primary metaphors is acquired automatically and unconsciously by functioning in everyday life. "Because of the way neural connections are formed," Lakoff and Johnson state "... humans all naturally think using hundreds of primary metaphors". They also endorse the view which is contrary to long-standing opinion, that primary metaphor is not the result of a conscious multistage process of interpretation, but is a "... matter of immediate conceptual mappings via neural connections" (Lakoff \& Johnson, 1999:57). They (1999:46, 47) develop an "integrated theory of primary metaphor" which includes four parts: Johnson's theory of conflation in the course of learning; Grady's theory of primary metaphor; Narayanan's neural theory of metaphor and Fauconnier and Turner's theory of conceptual blending. ${ }^{2}$ Conceptual metaphors are often conventional, they say. Lakoff and Johnson differentiate a set of metaphors they call "ontological metaphors". Ontological metaphors are the type of metaphor where abstract notions are thought of as concrete entities or substances. ${ }^{3}$ This grounding of primary and conceptual metaphor requires closer attention.

2 In conceptual metaphor theory metaphors are analysed as stable and systematic relationships between two conceptual domains, whereas in blending theory, the basic unit of cognitive organisation is not a domain but a "mental space" (Fauconnier, 1994:16). Mental space theory is based on the analysis of two or more input spaces, based on a generic space shared by both, and resulting in a blended space.

3 The term ontological is also used in the more conventional philosophical sense of the word when Lakoff and Johnson analyse Aristotelian categories and essences. I use the term ontic to refer to these phenomena. 


\subsection{Bodily nature of cognition and the nature of subjective experience}

Lakoff and Johnson's emphasis of the bodily nature of cognition also takes into account the multifaceted nature of the subjective experience of the world which forms the basis of analogical and metaphorical meaning change and meaning transfer. Their notion of embodiment and conceptual metaphor is based on an important assumption that "... our corporeality is part of the corporeality of the world ..." (Lakoff \& Johnson, 1999:565). The evidence they provide is based on extensive empirical analysis of "conceptual metaphor" and conceptual domains. When Lakoff and Johnson (1999:462) discuss the grounding of conceptual metaphor they argue that second-generation cognitive science locates meaning in the body and the unconscious conceptual system, and that meaning arises in the body and brain through our interactions with the environment and with other people (Lakoff \& Johnson, 1999:463). Cognitive semantics studies human conceptual systems, meaning and inference and claims that

... [m]etaphors are products of body, brain, mind, and experience, are pervasive in our everyday thought and in philosophy itself and get their meaning through the commonalities of the body and our bodily and social experience in the world (Lakoff \& Johnson, 1999:462, 463; 1988).

Lakoff and Johnson tie this innate human propensity to the embodied spirituality of human beings. This in turn comes to expression in what they call empathic imaginative projection - a form of "transcendence, ... a form of being in the other ..." (Lakoff \& Johnson, 1999:565) and in "ecological spirituality" (Lakoff \& Johnson, 1999:566) in the relationship to the physical world. "Embodied spirituality" entails that in all acts of imaginative, empathic interaction with the world around us an element of what has traditionally been called "the spiritual", is present (Lakoff \& Johnson, 1999:565). The fact that the analysis of metaphor leads to the recognition of the presence and role of embodied spirituality in the process of meaning formation, points to an important dimension of the discussion concerning the nature of metaphor, an issue that will be dealt with elsewhere.

\subsection{An ontological framework conditioning the "itineraries of meaning"}

My provisional agreement with Lakoff, Johnson and others about the "conceptual" nature of metaphor rests on an important caveat, viz. 
that this bodily based conceptual structure which lies at the basis of linguistic articulations of conceptual metaphor, is grounded in a deeper ontic structure of the world and of human experience. It is the "metaphorical" (actually "analogical") ontological structure of this grounding that needs to be "fleshed out" in a more encompassing framework. In such a framework the "multi-ordinality" or multifacetedness of reality, facts, things, human relationships, events, human action, human experience and cognition in diverse domains of experience, need adumbration. Such a framework must be able to ground the notion of "conceptual metaphor" and meaning in the ineradicably relational nature of both human beings and reality and in the relationship of human beings in and to reality. In order to escape the pitfall of subjectivism such a framework needs to accommodate the fact that concepts, conceptual domains and metaphors are constrained and conditioned by a deeper, ontological framework which conditions the "itineraries of meaning" (Ricoeur, 1980), which guide and structure the acts of knowing. These "itineraries" are not only constitutive of the human mind, but also of the nature of the world. In order to escape the trap of materialism, such a framework needs to recognise the bodily basis of human experience, conceptualisation and language without reducing this to its neural and bodily basis.

\subsection{Discerning recurring regulated patterns}

One's access to these ontic constraints and conditions are by means of human embodied experience and through linguistic or imaginative articulations. They are not created in these processes. Hart (1984) illustrates this point with a good example. If one were to fly over a major city and observe the obviously regulated patterns of traffic flowing beneath you, you would infer that there are traffic rules, and moreover, that these rules have been made by some competent body. When we recognise the fact that meaning is discerned on the basis of recurring regulated patterns, we are dealing with an analogous state of affairs. Discerning regularity and pattern and gestalts which constitute the basis of meaning does not imply that the meaning was created by the discerner.

Lakoff and Johnson's anchoring of meaning in the bodily existence falls short of actually recognising that all realms of reality are permeated by and pregnant with meaning which the knower in community with others opens up and dis-covers via human interactive experience. It is exactly this dynamic "... intrinsic restlessness and relational insufficiency of reality" (Hart, 1984:166), which human action and cognition participate in and which points to 
the "expressive" and "referential" character of all of reality where "... meanings refuse to stand still" (Van Hoozer, 1998:127). Both conceptual metaphor and the states of affairs on which it is based in reality have this deferral of meaning built into it. Having said this, it does not exempt us from the responsibility to track down the mechanisms by means of which we approximate such meaning. It is to the contours of this notion of "domains" that we now turn.

\section{Domains: structured mush?}

Lakoff $(1987: 268)$ recognises that a satisfactory account of meaning and meaningful understanding rests on the recognition of the structured nature of embodied, human experience. Experientialism, Lakoff claims (1987:267), rests on the bodily pre-conceptual form from which it arises and this is not "unstructured mush" (Lakoff, 1987:267). Lakoff says that

... conceptual structure is meaningful because it is embodied, that is, it arises from, and is tied to, our pre-conceptual bodily experiences. In short, conceptual structure exists and is understood because pre-conceptual structures exist and are understood. Conceptual structure takes its form in part from the nature of pre-conceptual structures.

Lakoff and Johnson $(1980: 117,118)$ argue that there are three natural kinds of experience: of the body, of the physical environment, and of the culture. They regard them as "natural" because they are products of human nature (Lakoff \& Johnson, 1980:116). There is a relatively small number of conceptual metaphors drawing on domains of bodily experience which structure abstract human concepts (Johnson, 1989:115). Johnson claims that our knowledge is embodied in a deeper and more profound sense than mere know-how. Our conceptual system "... is grounded in and structured by various recurring patterns of our perceptual interactions, bodily orientations, movements and manipulations of objects" (Johnson, 1993a:414). He states that this "... corporeal semantics, a semantics of embodied understanding" (Johnson, 1993a:422) actually is constitutive of our cognitive activity and of our concepts. So one can conclude that in their view human embodied nature and cognition are patterned and orderly, and that this order reflects in the concepts formed in and about the world. It is the nature of the pre-conceptual reality that needs further reflection. 


\subsection{Metaphors rest on some form of analogy}

Metaphors always rest on some form or sort of analogy that relates to differences and/in similarities, albeit within domains or between different domains. Metaphors are not only lingual articulations of purported interactive meanings between two different semantic domains or between differences and similarities within one domain, but are also typical of thought processes about the world. They express more than merely lingual states of affairs, but rely on ontic categories, (natural) kinds and image schemata, and in turn "create" (Fauconnier, 1994) domains or "mental spaces". Image schemata are pre-conceptual experiences that occur constantly in everyday life, e.g. orientations and relations (up-down, part-whole, centreperiphery, etc. - Lakoff, 1987:267).

\subsection{Domains and mental spaces not only creations of the human mind}

There is no doubt that the human mind is actively involved and creative in the process of uncovering and opening up new domains. The recognition of this creative act needs not commit one to a position in which the existence of these domains are ascribed primarily to the outcomes of neural mechanisms. That our recognition and knowledge of such domains are based on effective neural processes requires little argument, but this does not point to the neural origin of such domains. The tendency toward transcendence mentioned above is an indication that even in our most creative and imaginative moments we succeed only in gaining limited in-sight into a part of the deep and unfathomable complexity of meaning which precedes our cognitive or linguistic grasp and which seems always to be unfolding more layers and depths of meaning. A reading, which ultimately attributes "domains" and "mental spaces" to creations of the human mind does not satisfy, because in this view, meaning is merely the result of human physical and mental processes. All these processes play a significant role in meaning creation and change, but fail to provide an adequate and convincing grounding of meaning. Meaning and metaphorical meaning can not be a bootstrap operation in which all resources of meaning are only embedded in the subject or in the material, neural basis. On the contrary, meaning is presupposed when human actors interact with the world. It is to the possible structure of this presupposed meaning that we now turn. 


\section{Domain theories}

The early relatively simple definition of metaphor as the understanding of one domain of experience in terms of another domain of experience raised a fundamental question: What are "domains of experience"? (Lakoff \& Johnson, 1980:117; Brandt, 2000:12). The notion of a domain is found in the earliest literature on metaphor, e.g. in terms like source domain and target domain but is not explicitly defined. Brandt (2000:11-51) shows that a few authors (Lakoff \& Johnson, Turner, Sweetser) have done work in this area, but argues that no adequate account of domains has yet been developed. He then proceeds to develop an "architecture of semantic domains as grounding hypothesis in cognitive semiotics" (see Brandt, 2000). This proposal is preceded by Eve Sweetser's (1990:19) analysis of semantic change and polysemy patterns in which she introduces at least four systematic metaphorical connections between domains: social, physical, mental and speech acts. Sweetser (1990:19) states the following:

Metaphor operates between domains. It operates so pervasively that speakers find an inter-domain connection between knowledge and vision, or between time and space, to be as natural as the intra-domain connection between finger and hand or between man and woman.

\subsection{Per Aage Brandt's proposals}

Per Aage Brandt (2000) presents a "geography of the life-world" and provides an "architecture of semantic domains as a grounding hypothesis in cognitive semiotics" (see Brandt, 2000). He claims that we are embodied according to different basic domains of reality and calls for a return to the inaugural studies of metaphor and shows that "metaphor concepts are superordinate semantic indicators of domain addresses" (Brandt, 2000:48). In his "first life-world map" he distinguishes a total of four basic gesture-based semantic domains: the physical, the social, the mental, and the speech-act domains (D1, D2, D3 and D4) and three action-based satellite or practical domains: work, love and worship (D5, D6 and D7). To this he adds a second and third satellite generation of domains that are exchanged-based (D8-D10): jurisdiction, economic exchanges, aesthetic evaluations in cultural life, and three fundamental genres of discourse (D11-D13): argumentative, narrative and descriptive (Brandt, 2000:45). This approach chooses gesture, action, exchange and discourse as the four main categorisations of domains. To what extent such a categorisation is productive of 
actual insight into the process of meaning creation obviously depends on the type of problems it is able to solve or the number of approaches it can accommodate. I avoid a critical discussion of these two approaches in order to give attention to an alternative which accommodates the idea of ontic conditions basic to the distinction of domains and meaning.

We now have a number of arguments that allude to the existence of some ontological, experiential and/or embodied grounding of metaphorical meaning and meaning change. These positions have in common that they deny the existence of a "... rock-bottom core of literal concepts to which all meaning or conceptual structure can be reduced", yet do suggest some basic experiential grounding (Johnson, 1993a:421). It is about the nature of the embodied experiential grounding that views diverge. Obviously all three sets of proposals above have merit and share one common denominator, that is, their approach to the grounding of metaphorical meaning from the angle of cognitive linguistics and cognitive semantics (Brandt would prefer to call it cognitive semiotics).

Brandt's proposals have a continental philosophical flair which reminds strongly of Husserlian phenomenological (life-world) roots, but his analyses are very much in the style of cognitive linguistics with its close attention to sentence structure and meanings of single concepts. Brandt has left "domain theory" behind and wants to work with "mental spaces" (along the lines of Fauconnier), presumably grounding the nature of meaning in the mental capacities of human beings.

Brandt's (2000) proposal and methodology of an architecture of semantic domains recognises the bodily basis of semantic domains and multi-modal gestalts (Brandt, 2000:19), and develops a taxonomy of domains in the proposed "first life-world map" (Brandt, $2000: 13)$. His appeal to the "life world" is an important step in the right direction as is the proposal of Lakoff and Johnson to ground metaphorical meaning in experiential gestalts and human embodiment. It is true that meaning comes to expression in a variety of speech acts, facts, events, things, societal relationships, etcetera and that all incorporate some form of metaphorical language.

\subsection{Lakoff and Johnson's emphasis - embodied realism}

Lakoff and Johnson's emphasis on embodiment as the basis of meaning is a choice for an anthropocentric grounding. They claim that it is mistaken to think that the spatial relations our conceptual 
system relies upon and which we take for granted, are just "... objectively given features of the external world" (Lakoff \& Johnson, 1999:575). They argue that we make the best of what our brain and our visual system offer us of this world. In this quote, as in other sections of the 1999 major work of Lakoff and Johnson, embodied realism locates metaphorical meaning in the body, the brain and the neurological functioning of the human brain. Their view seems to lack recognition of the stratified nature of non-human reality, which correlates with the stratification of human embodied experience. They locate and explain metaphorical polyvalence on the basis of embodiment without recognising the pre-given ontic basis for this multivalence. Metaphorical polyvalence still requires some deeper ontological grounding, certainly more than grounding merely in human mental capacities.

There is also another important dimension of metaphorical meaning that is not adequately addressed in these approaches: a certain type of conceptual metaphor expresses the analogical radial structure of meaning harboured in diverse aspects of reality. There is a need for a theory that explains the fact that this type of conceptual metaphor embodies, what Clouser (1991:215) calls "aspectual universality". This is the phenomenon that in all domains all other domains seem to be echoed or reflected.

\subsection{The concept of radial structure}

An important clue to both the problem of conceptual and metaphorical multivalence and polysemy on the one hand, and the ontological bases for aspectual universality, is to be found in the idea of the "radial structure" of categories. This concept of radial structure as I propose to use it, differs from the way it is used by Lakoff and Johnson: Radial structure should not to be seen as predominantly a conceptual matter, but primarily and ontological (actually "ontic") matter. Reality, both in its entitiary and aspectual existence, reflects the diverse coherence of meaning nuances. It is the ontological assumptions of such a conception of domain grounding of knowledge 4 and metaphor that requires further fleshing out. I propose to deal with this in the next section. In this section I have broken with the "double-language thesis" and its conventional grounding of meaning in the literal. It has also broken with an understanding of embodied realism which denies that we live and 
experience a world "given" to us. There is no "earthly world"-in-itself, but only one that stands in a "concentric relationship" (Dooyeweerd, 1955:549) to humankind. 5 But this view cannot imply that all facets of reality and all human experience of reality can ultimately be grounded in neural processes or human embodiment.

\section{Cross-domain mappings and radial categories}

Lakoff and Johnson (1980:117) answered the question concerning the nature of domains of experience by referring to "natural kinds of human experience". They (Lakoff \& Johnson, 1980:117, 118) argue that there are three natural kinds of experience viz. "experiences of the body, of the physical environment, and of the culture". They constitute the source domains upon which metaphors draw. Understanding takes place in terms of entire domains of experience and not in terms of isolated concepts. They indicate that "domains of experience" are structured wholes within recurrent human experience that are organised as experiential gestalts. These experiences seem to be natural kinds of experience in the sense that they are products of human nature (Lakoff \& Johnson, 1980:117). Some of these experiences may be universal and others vary from culture to culture. In their later work, Philosophy in the flesh (Lakoff \& Johnson, 1999) "domains" are not explicitly defined. In their view of "cross-domain mapping" and "radial categorisation" (or "radial structure") (Lakoff \& Johnson, 1999:177, 224, 225, 233, $500,501,512)$, one finds an indication of what this idea of "domains" actually entails.

Lakoff and Johnson (1999:77) state that the empirical results of the work of second-generation cognitive science led to the abandonment of the key assumptions of Anglo-American "cognitivism". Two kinds of evidence were provided by this new research:

$5 \quad$ This calls forth a number of philosophical issues which can not be dealt with in this article. Within the tradition of Reformational Christian philosophy there has been a significant difference between the positions of Stoker and Dooyeweerd $(1957: 74,75)$ on this matter: The former argues that all realms (inanimate, vegetative, animate and human realms) have their own intrinsic meaning and relationship to God. Dooyeweerd on the other hand, argues for an anthropocentric, (con-)centring of reality in human embodiment and relations. This stance in turn is grounded in the transcendent and transcendental a priori structure of reality which conditions human experience and makes human experience and knowledge possible (Dooyeweerd, 1955:548). 
(1) a strong dependence of concepts and reason on the body and

(2) the centrality to conceptualization and reason of imaginative processes, especially metaphor, imagery, metonymy, prototypes, frames, mental spaces, and radial categories.

Basic-level conceptualisation is the cornerstone of "embodied realism", they say (Lakoff \& Johnson, 1999:74-93). Metaphorical language is a reflection of metaphorical thought. Metaphorical thought in the form of cross-domain mappings is primary; metaphorical language is secondary" (Lakoff \& Johnson, 1999:123). To this they add (Lakoff \& Johnson, 1999:543) “... metaphors ground abstract concepts through cross-domain mappings using aspects of our embodied experience ... Metaphors are the very means by which we can understand abstract domains and extend our knowledge into new areas."

\subsection{Different domains}

The term domain is used to indicate domains of conceptual metaphors, linguistic domains, semantic domains, domains of experience, etc. "Cross domain conceptual mapping" (Lakoff \& Johnson, 1999:71) is described as a "cognitive mechanism" which is based on the existence of "conceptual metaphor", an embodied system of "basic-level concepts" that "... have evolved to 'fit' the ways our bodies, over the course of evolution, have been coupled to our environment" (Lakoff \& Johnson, 1999:91). Each metaphorical idea which is binary and not unitary harbours a cross domain mapping - "... it has both a source and a target that is at least partly structured by that source" (Lakoff \& Johnson, 1999:255). Fundamental to the domains are categories and prototypes. A prototype is the most central, or typical instance of a category. Whereas "radial categories" are extensions of the prototype, they are less "typical", and may differ from the prototype in one or more features.

\subsection{A radial category has one central case}

In a radial category there is one central case and the others are extensions of the central one. The example which they use to illustrate this is "harm". The central kind of harm is physical, but there is also emotional, financial and social harm which form metaphorical extensions of the central case. They may represent metaphorical extensions of the prototype (as in "harm"), or 
alternatively, categories that are missing one or more features associated with the prototype (as in "mother"). Lakoff and Johnson (1999:224) claim that our very concept of causation is multivalent: it consists of the entire radial structure, with human agency at the centre and many extensions. The word "causation", they say "... designates a human category, a radial category of extraordinary complexity". We have a central prototypical case of what "causation" is in our physical experience of for example being punched in the arm, but, Lakoff and Johnson (1999:233) argue, "the question is, however, problematic just about everywhere else, because we are moving away from the central prototypical case of causation to other very different senses with different logics and different criteria for determining what is true". Thus causality differentiates according to a great variety of contexts or aspects of human experience and reality.

The above-mentioned differentiation according to a variety of contexts raises the question concerning differentiation between the (centrally prototypical) meaning of causality and the differentiated analogical meanings of causality which are found within the radius of the domain inhabited by the prototypical case. How is this determined? Some ontological distinctions found in the philosophy of Herman Dooyeweerd are helpful in this respect.

\section{Experiential and embodied domains: an alternative view}

The alternative view of the domains and radial categories involved in experience and embodiment proposed in this section of the article is based upon basic distinctions found in the Philosophy of the Cosmonomic Idea of Herman Dooyeweerd (cf. 1953; 1955 and 1957). The following are some of the distinctions most relevant to the topic under discussion:

- All entities in reality and human experience function in a diversity of mutually coherent but irreducible aspects or facets of reality also called modal or functional domains.

- This diversity of coherent but mutually irreducible modal domains exhibit both similarities-in-differences and differences in their similarities - also called modal or functional analogies.

- Analysis of the world around us rests on the identification and distinction of these similarities and differences exhibited by entities and/or aspects or facets of entities. 
- Concept formation rests on the identification of such similarities and differences in which features that have been identified and distinguished are united in a concept.

The quest for a literal grounding of meaning associated with the double-language thesis needs to be replaced by a grounding of meaning in the distinction between non-analogical (or original) modal meaning juxtaposed to analogical modal meaning.

On the basis of these assumptions it is important to differentiate clearly between the standard usage of the term metaphor as found in theories about poetry, prose and literature, and the more sophisticated way in which it is often used in metaphor theory where it indicates deeper ontological, orientational and structural states of affairs. The latter type of metaphors inevitably incorporate some form of ontic analogy. In order to differentiate the conventional understanding of metaphor from conceptual metaphors and a deeper type of ontological (ontic) "metaphor" a provisional distinction between metaphor and analogy is introduced.

\subsection{Metaphor and analogy}

Metaphor indicates any statement or utterance which understands some concrete domain of human experience and reality in terms of another concrete domain of experience and reality. Concrete entities can be any fact, thing, event, action and societal relationship. So for example "education is gardening," "therapy is archeological excavation" or "parental love is a never ending stream", "the state is a system" are examples of metaphors relating two (concrete) entities, even though some of the source or target domains are actually "abstract" in the conventional sense of the word. This distinction is based on one in which two kinds of "domains" can be discerned: entitiary domains and modal or functional domains. 6 The focal analogical moment which is often the "point" of a metaphor is embedded in the semiotic radius and/or semantic field of an ontic

6 With this distinction in place the notion of metaphor becomes more refined and requires further specification when used within the context of the systematic distinctions of Herman Dooyeweerd's philosophy. Also Strauss (1988: diagram 3) distinguishes between metaphors and analogies on the following basis: Metaphors are linguistic in nature and are entitiary analogies that pertain to similarities and differences between entities in reality, whereas similarities and differences between aspects of reality are indicative of modal analogies that come to expression in the elementary basic concepts of disciplines. I have one caveat to this definition: "metaphor" does not only need to be linguistic in nature (cf. Botha, 1988). 
domain. So for example one can discern different emphases or foci in the use of the term system. A metaphor in which an organic system like a plant is utilised in the target domain would accentuate the biotic analogical element in the relationship, whereas a mechanical system metaphor accentuates the mechanical analogy. To use "mental space" theory here, one could say that the "blended space" which comes to expression in the metaphor of an organic system differs from the blended space resulting from the use of the mechanical-system metaphor. The main reason for this is the fact that in the actual input space-"system" the (analogical) moments in the two examples mentioned are configured differently because of a different analogical focus.

Analogies express the a-similarity-in-difference or differences-insimilarities, between two concrete entities. Entities can be any fact, thing, event, action or social (societal) relationship. These analogical relationships are often mediated by and articulated in lingual metaphors. Not only is there an infinite number of potential analogies present in any such relationship, but some are already known as existing and recognisible analogical elements, whereas others are "created" in the course of the opening up of the potential analogies present in the semiotic radius and/or semantic field of the domains in which the analogy occurs. "Analogy", in this philosophical approach, indicates a relationship between aspects, facets or dimensions (also called "properties" or "irreducible kinds of functionality" - Hart, 1984:149 ff.) of concrete entities. Examples of such modal analogies are "economic growth", "social distance", "psychological stress", "political movement", etcetera. These analogies are anchored to or moored in irreducible kinds of functionality which constitute the semantic domains that anchor or ground meaning and also form the basis of the multiplicity of meanings that metaphors and analogies reveal.

\section{The Principle of Aspectual universality}

Dooyeweerd (1954) differentiates between different types of mutually cohering but irreducible (origin-al) domains in reality and human experience. In each one of the irreducible aspects or facets of reality and of human experience the whole spectrum of other domains is mirrored and comes to expression in the process of concept formation. Every human act (thing, fact, event, entity, societal relationship) in principle exhibits all these (and most probably more) aspects or facets either passively or actively. In each one of these dimensions all of the rest of reality is reflected or echoed. This process is called the "Principle of Aspectual 
universality" (Clouser, 1991:215). A possible metaphorical image to portray this process of reflection or echoing is the result of a prism breaking up unified white light into the spectrum of rainbow colours. One could also speak of the "focal hues" of white light.

Each irreducible ontic domain is characterised by an original7 or non-analogical modal nucleus or kernel - the most basic common denominator or irreducible core (Hart, 1984:157) for the type of functioning characteristic of that aspect of reality. One is tempted to say this meaning nucleus is the "literal" core, but the fact that this core expresses itself via analogical relationships rules out this language use. For example, the (origin-al) meaning nucleus of the economic mode of reality could be formulated as "frugality", whereas the meaning nucleus of the spatial aspect would be "continuous extension" and that of the aesthetic aspect as "allusiveness", etcetera (Seerveld, 1980:131). Every thing, fact, event, act and societal relationship can be approached from any one of these modal angles and the active or passive presence of this aspect can be discerned in all of reality and human experience. The "modalities" or functional aspects "... form a modal framework in which we grasp concrete phenomena from different points of view" (Dooyeweerd, 1954 as translated by Knudsen). What makes this modal core or nucleus remarkable is the fact that it can only come to expression via a vast number of analogical elements. Thus in effect a multiplicity of potential and embryonic hierarchically ordered meanings is already present in the core or origin-al or nonanalogical meaning of an irreducible aspect of reality (not only of human experience).

\subsection{Substrate modalities are assumed in analogical concepts}

In analogical concepts the preceding aspects (substrate modalities) are assumed and subsumed, for example, one cannot say space without implying that this concept also entails number/countability. One cannot use any concepts that refer to movement without implicitly assuming or implying both space and number. Things that move occupy space and can be counted. These are necessary conditions (cf. Hart, 1984:159). One cannot use the concept social without assuming the analogical elements of other aspects. It presupposes space, discrete quantity, countability, movement, logically discrete identity and difference, communication via

7 "Original is the qualifier of a term used to indicate univocally the irreducible, nonanalogical core nature of a functional mode" (Hart, 1984:161). 
language formulated in concepts, sentences, historical/cultural formation, etcetera.

\subsection{The possibility of opening up dormant aspects}

Implicit in such concepts are also the possibilities of interactively opening up passive aspects that are dormant (projections?) of other subjects or objects. These projections are related to human experience and possibilities, i.e., perceivability, quantifiability, economic exploitation, ethical evaluation, etcetera. Thus a physical entity like a piece of rock (gold) can be mined as international economic commodity, but it can also be developed in precious jewelry (aesthetic) or be presented as a token of love (ethical troth). The last three examples demonstrate the way in which dormant/passive aspects of a rock are interactively opened up by human (normative) intervention. The peculiar characteristic of the aspectual nucleus is the fact that it colours an aspect of reality and in turn reflects the full scope of the inter-modal coherence of the irreducible aspects of reality. Lakoff and Johnson would attribute these potential and dormant functions which conceptual metaphors can actively open up, to the human embodied experience. Obviously that is true, but the fact remains that these non-human entities intrinsically possess these potential qualities and or properties that can be un-covered through human experience.

Causality in its origin is a physical phenomenon, but can be seen from a great diversity of vantage points. From a legal perspective legal causality (who is legally to blame) implies an analogical relationship (or cross-domain "mapping") between the physical and juridical domain. From an ethical perspective the ethical analogy of "ethical causality" (who is morally guilty), and from a social perspective the social analogy or "social causality" (social responsibility, e.g. an impaired driver), represent cross-domain mappings. This example can be expanded to include the economic analogy, "economic causality" (costs of the accident), etcetera. The radial categories within the physical domain thus show an original (or non-analogical) and analogical use of concepts demonstrated by the notion of causality. Obviously such analogical refractions of a core origin-(al) meaning reflect a multiplicity of possible domains and cross-domain mappings, and these domains are in turn grounded in the experience of embodied persons. 


\section{Personhood: A stratified embodiment}

In the creative and interpretive interaction with the world embodied human experience provides the basic experiential gestalts, image schemata and conceptual metaphors that make up the framework which functions as scaffolding for the network of meanings which language and specifically conceptual metaphor reveal. The way these cognitive abilities function point to an irreducibly stratified embodiment of both the cognitive agent and the world she is cognitively interacting with. The challenge is to demonstrate how the conditions for this irreducibly stratified reality is recognised, discovered or approximated by the agent (and not created by the agent) and how it constrains metaphorical meaning and meaning change. This recognition requires an understanding of embodiment8 which correlates to the purported contours of stratified, irreducible dimensions of reality. This view implies a view of personhood which acknowledges the stratified embodiment of the whole, integral human person in his/her relationship to himself, others, cultural artifacts, the nonmaterial, vegetative and animal worlds and ultimately to what he or she believes to be God or a deity.

Human personhood is centred in an integral embodied existence which manifests more than what has traditionally been called the "body", i.e. only the physico-chemical, biotic and sensitive dimensions of human existence. Acts performed by the human person always involve the full "soul-bodied person" in whose activities one is able to discern a great diversity of aspects or facets and complex levels of structures. All human acts are enacted by the full integrated person (not only by bodies, souls or minds or spirits). These actions take place within the limits of the constraints set by a great diversity of aspects, facets or functions of human life and reality. This notion of personhood aims to overcome the soul-body dichotomy/dualism, the subject-object divide, the body-consciousness (mind) opposition, and aims at avoiding the trap of seeing cognition primarily as representation, and truth as correspondence with reality. It also grounds embodiment in the transcendental conditions that make its existence possible. It postulates at least four different overlapping "bodily" structures that presuppose one another and that are simultaneously involved in all human acts (Johnson [1991] refers to a similar state of affairs but calls it "overlapping patterns").

8 Cf. Tim Rohrer's summary of the tenfold meanings of embodiment (Rohrer, 2001: 1.49 82). Cf. also Rohrer (2005). 
The way full-bodied humans interact with the world around them sets the stage for an alternative understanding of the interactive nature of human knowledge and the inter-domain relationships to which metaphors refer. These irreducible domains of embodied humankind are interlaced: each having its own identity but also building on one another and depending on one another. These irreducible domains are the physico-chemical (inorganic), the biotic (organic), vegetative, the physico-chemical, psychic (sensitive), and the human act structure which incorporates all normative dimensions of human existence and is open ended in the sense that the acts it produces can be qualified in a multiplicity of possible ways.

\subsection{Each domain forms the substrate for the domain "above" it}

Each one of these irreducible domains forms the substrate for the domain "above" it. This "hierarchy implies that the neural grounding of metaphorical meaning is an essential and constitutive basis of all other forms of meaning, e.g. linguistic meaning presupposes sensitive, organic and physico-chemical substrates. Social communication in turn presupposes the bases just mentioned and also human lingual and cultural abilities. Even though these constitutive bases can be discerned in all metaphorical construals of meaning, metaphorical meaning cannot be reduced to its material neural basis.

The alternative approach suggested in this article counteracts subjectivism and materialism in the following ways:

- By recognising the irreducibility of domains in reality and the irreducibility of different act structures within human embodiment it avoids any form of reductionism.

- By acknowledging the radial structure of these irreducible domains recognition is given to the intrinsic coherence of all spheres of reality which in turn rules out absolutist claims that ground meaning only in one dimension of reality.

- In final instance the irreducibility of domains appealed to and demonstrated above as "grounding" for metaphorical meaning acquire their universal meaning stability from the fact that they are conditioned by a design plan or order. 
List of references

BOTHA, M.E. 1988. Framework for a taxonomy of metaphor. Philosophia Reformata, 53:1.

BRANDT, P.A. 2000. The architecture of semantic domains: a grounding hypothesis in cognitive semiotics. Revista Portuguesa de Humanidades, $4(1 \& 2): 11-51$.

CLOUSER, R.A. 1991. The myth of religious neutrality: an essay on the hidden role of religious belief in theories. Notre Dame: University of Notre Dame Press.

DOOYEWEERD, H. 1953. A new critique of theoretical thought. Translated by David $H$. Freeman and William S. Young. Vol. 1: The necessary presuppositions of philosophy. Amsterdam: Paris.

DOOYEWEERD, H. 1954. De analogische grondbegrippen der vakwetenschappen en hun betrekking tot de structuur van den menschelijken ervaringshorizon. Mededelingen der Koninklijke Nederlandsche Akademie van Wetenschappen, afd. Letterkunde. New Series, 17(6):171-192. Translated by Robert D. Knudsen as The analogical concepts. Amsterdam: Noord-Hollandsche Uitgeversmaatschappij.

DOOYEWEERD, H. 1955. A new critique of theoretical thought. Translated by David $\mathrm{H}$. Freeman and $\mathrm{H}$. de Jongste. Vol. 2: The general theory of modal spheres. Amsterdam: Paris.

DOOYEWEERD, H. 1957. A new critique of theoretical thought. Translated by David $H$. Freeman and $H$. de Jongste. Vol. 3: The structures of individuality of temporal reality. Amsterdam: Paris.

FAUCONNIER, G. 1994. Mental spaces: aspects of meaning construction in natural language. Cambridge: Cambridge University Press.

HART, H. 1984. Understanding our world: an integral ontology. Lanham: University Press of America.

JOHNSON, M. 1987. The body in the mind: the bodily basis of meaning, imagination and reason. Chicago: University of Chicago Press.

JOHNSON, M. 1989. Image-schematic bases of meaning. Semiotic Inquiry, 9(13):109-118.

JOHNSON, M. 1991. Knowing through the body. Philosophical Psychology, $4(1): 3-18$.

JOHNSON, M. 1993a. Conceptual metaphor and embodied structures of meaning: a reply to Kennedy and Vervaeke. Philosophical Psychology, $6(4):. 413-422$.

JOHNSON, M. 1993b. Moral imagination: implications of cognitive science for ethics. Chicago: University of Chicago Press.

KENNEDY J.M. \& VERVAEKE, J. 1993. Metaphor and knowledge attained via the body. Philosophical Psychology, 6(4):407-412.

LAKOFF, G. 1987. Women, fire and other dangerous things: what categories reveal about the mind. Chicago: University of Chicago Press.

LAKOFF, G. \& JOHNSON, M. 1980. Metaphors we live by. Chicago: University of Chicago Press.

LAKOFF, G. \& JOHNSON, M. 1988. Cognitive semantics. (In Eco, Umberto et al. Meaning and mental representation. Indiana: Indiana University Press. p. 119-154.)

LAKOFF, G. \& JOHNSON, M. 1999. Philosophy in the flesh: the embodied mind and its challenge to Western thought. New York: Basic Books. 
LAKOFF, G. \& TURNER, M. 1989. More than cool reason: a field guide to poetic metaphor. Chicago: University of Chicago Press.

RICOEUR, P. 1980. Bible and imagination. (In Betz, H.D. The Bible as document of the university. Polebridge Books: Scholars Press. p. 49-75.)

ROHRER, T. 2001 Pragmatism, ideology and embodiment. (In Dirven, R., Hawkins, B. \& Sandikcioglu, Esra, eds. Language and ideology. Vol. 1: Theoretical and cognitive approaches. Amsterdam: John Benjamins. p. 4982. Also on web: http://zakros.ucsd.edu/ 10hrer/embodiement

ROHRER, T.C. 2005. Embodiment and experientialism. (In Geerarts, D. \& Cuyckens, $\mathrm{H}$., eds. The handbook of cognitive linguistics. Oxford: Oxford University Press. p.49-81.)

SEERVELD, C. 1980. Rainbows for the fallen world. Toronto: Tuppence.

STRAUSS, D.F.M. 1988. Die grondbegrippe van die Sosiologie as wetenskap. RGN-ondersoek na Navorsingsmetodologie. Pretoria: Raad vir Geesteswetenskaplike Navorsing. (Navorsingsverslaereeks, 8.)

SWEETSER, E. 1990. From etymology to pragmatics: metaphorical and cultural aspects of semantic structure. Cambridge: Cambridge University Press.

VAN HOOZER, K.J. 1998. Is there a meaning in this text? The Bible, the reader and the morality of literary knowledge. Grand Rapids: Zondervan.

\section{Key concepts:}

anthropological grounding

conceptual metaphor theory

domain theory

metaphorical meaning: grounding of

ontological grounding of metaphorical meaning

radial categories

\section{Kernbegrippe:}

antropologiese begronding

domeinteorie

konseptuele metafoorteorie

metaforiese betekenis: begronding van

ontologiese begronding van metaforiese betekenis

radiale (straalvormige) kategorieë 
